\begin{tabular}{|l|l|l|}
\hline \multicolumn{2}{|c|}{ PublisherInfo } \\
\hline \hline PublisherName & $:$ & BioMed Central \\
\hline \hline PublisherLocation & $:$ & London \\
\hline \hline PublisherImprintName & $:$ & BioMed Central \\
\hline \hline
\end{tabular}

\title{
How melanomas avoid apoptosis
}

\begin{tabular}{|l|l|l||}
\hline \multicolumn{2}{|c|}{ ArticleInfo } \\
\hline \hline ArticleID & $:$ & 3953 \\
\hline \hline ArticleDOI & $:$ & $10.1186 /$ gb-spotlight-20010112-02 \\
\hline \hline ArticleCitationID & $:$ & spotlight-20010112-02 \\
\hline \hline ArticleSequenceNumber & $:$ & 24 \\
\hline \hline ArticleCategory & $:$ & Research news \\
\hline ArticleFirstPage & $:$ & 1 \\
\hline \hline ArticleLastPage & $:$ & 2 \\
\hline \hline & $:$ & RegistrationDate : 2001-01-12 \\
ArticleHistory & $:$ & OnlineDate \\
\hline \hline ArticleCopyright & $:$ & BioMed Central Ltd2001-01-12 \\
\hline \hline ArticleGrants & $:$ & \\
\hline \hline ArticleContext & $:$ & 130592211 \\
\hline \hline
\end{tabular}




\section{William Wells}

Email: wells@biotext.com

Many cancers become resistant to chemotherapeutic drugs thanks to loss of the $p 53$ protein, which promotes cell cycle arrest and apoptosis in response to certain drugs. Metastatic melanomas are unusual in that, despite their chemoresistance, they retain functional $p 53$. In the January 11 Nature, Soengas et $a l$. find that these melanomas still lose the $p 53$ pathway thanks to deletion and methylation of the $p 53$ effector Apaf-1 (Nature 2001, 409:207-211). The Apaf-1 locus shows over 40\% loss of heterozygosity in melanomas, and in these cells the remaining Apaf-1 gene is no longer expressed. Expression and chemoresistance can be reactivated by addition of either a methylation inhibitor or a functional Apaf-lgene.

\section{References}

1. Malignant melanoma: modern black plague and genetic black box.

2. Nature, [http://www.nature.com/nature/]

This PDF file was created after publication. 